\title{
Possible Significance of Advanced Glycation End Products in Serum in End-Stage Renal Disease and in Late Complications of Diabetes ${ }^{1}$ )
}

\author{
Roswitha Dolhofer-Bliesener, Brigitte Lechner and Klaus-D. Gerbitz
}

Institut für Klinische Chemie und Institut für Diabetesforschung, Städtisches Krankenhaus München-Schwabing, Akademisches Lehrkrankenhaus der Universität München, München, Germany

Summary: Advanced glycation end products were determined immunologically in blood from diabetics, patients with renal failure and subjects with various other diseases. Elevation of advanced glycation end products levels in serum is not confined to the diabetic state but was also observed in some severely ill subjects. Patients with endstage renal disease on dialysis displayed high advanced glycation end products levels in serum, irrespective of the presence or absence of diabetes. In contrast, advanced glycation end products levels in uraemic subjects not treated by dialysis were not different from controls. In diabetics, levels of advanced glycation end products were related to the state of late complications. Diabetics without sequelae showed advanced glycation end products within the normal range, whereas in the presence of late complications mean advanced glycation end products levels were elevated. In the case of retinopathy the increase in advanced glycation end products was associated with the severity of retinal status.

\section{Introduction}

Prolonged exposure to high glucose levels is thought to be an important factor for the development of diabetic late complications. One possible mechanism, contributing to diabetic sequelae, might be the increased formation of advanced glycation end products during hyperglycaemia. In the first step of this reaction, reducing sugars such as glucose are covalently attached to free amino groups of proteins to form labile Schiff bases which subsequently undergo Amadori rearrangement to stable ketoamines. Formation of Amadori products is well established for a number of proteins and has been found to be increased in diabetes (for a review see l.c. (1)). The Amadori product undergoes very slowly a series of rearrangement reactions leading to a large number of different compounds, called advanced glycation end products and abbreviated as AGE (2). Advanced glycation end products may be implicated in the development of diabetic late complications either by their direct chemical reactivity, e. g. crosslink formation (3), trapping of plasma proteins (4), generation of free radicals (5) or inactivation of nitric oxide (6), or by their indirect actions such as stimulation of cytokine formation (7) or enhancing synthesis of extracellular matrix components or cell proliferation (8), respectively (for a review see (9)).

1) Funding organisation: Deutsche Forschungsgemeinschaft, Bad Godesberg, Germany
The nature of advanced glycation end products is still unknown. Some discrete products such as pyrraline (5hydroxy-methyl-1-alkylpyrrole 2-carbaldehyde) (10), pentosidine (imidazo(4,5-b)pyridinium) (11) and 3deoxyfructose and 3-deoxyglucosone (12) have been found to represent advanced glycation end products formed in vivo and to be present in human serum proteins and tissues. Furthermore, advanced glycation end products have been detected in high and low molecular forms in human serum, surprisingly showing their highest levels in subjects suffering from end-stage renal disease $(13-16)$.

Until recently, measurement of advanced glycation end products was impeded by the lack of specific and sensitive assays. Some advanced glycation end products exhibit fluorescence at $440 \mathrm{~nm}$ upon excitation at $370 \mathrm{~nm}$ (17), however, fluorescence can also result from the reaction between lipid peroxidation products and proteins (18) or from the oxidation of amino acids by free radicals $(19,20)$. Measurement of specific advanced glycation end products like pentosidine, may underestimate the quantities of advanced glycation end products in tissues and serum. In this study advanced glycation end products were determined immunologically with an antiadvanced glycation end products antibody which recognizes epitope(s) common to a large number of different advanced glycation end products $(16,21,22)$. Measurement was performed in blood from apparently healthy subjects, diabetics, patients with renal diseases and from non-diabetic, non-uraemic patients. Evidence is presented that the levels of advanced glycation end pro- 
ducts in serum are related to diabetic late complications rather than to kidney failure, and furthermore that dialysis per se might lead to an enhancement of advanced glycation end products.

\section{Materials and Methods}

Serum or heparin plasma was obtained from 25 normal healthy persons (22-60 years old), from 31 non-diabetic patients with endstage renal disease (33-87 years old; 19 on haemodialysis and five on continuous ambulatory peritoneal dialysis), from 12 nondiabetic, non-uraemic patients with various diseases (18-88 years) and from 85 diabetic patients (16-93 years of age). Twenty-nine of the diabetics suffered from end-stage renal disease, 18 were treated with haemodialysis and three with continuous ambulatory peritoneal dialysis. Duration of diabetes ranged from newly discovered to 40 years. Of the diabetics without end-stage renal disease 24 were treated with insulin, 16 with oral antidiabetics, 9 with insulin in combination with oral antidiabetics and 7 with diet alone.

Advanced glycation end products were detected immunochemically in a competitive ELISA using an antibody prepared by our group according to Nakayama et al. (21). Characterization of the anti-advanced glycation end products antibody and performance of the assay have been described in detail previously $(16,22)$. Briefly, advanced glycation end products human albumin was prepared in vitro by incubating $43.3 \mu \mathrm{mol} / \mathrm{l}$ albumin for 34 days at $37^{\circ} \mathrm{C}$ with $55.5 \mathrm{mmol} / \mathrm{h}$ glucose at $\mathrm{pH} 9.5$. For performance of the assay onehalf of a microtitre plate (Nunc immunoplates) was coated by adding $0.1 \mathrm{ml}$ advanced glycation end products human albumin, 0.5

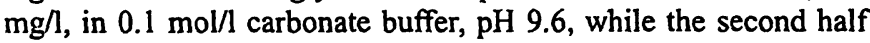
was coated with human albumin incubated in the absence of glucose, these wells serving for the blank values. After incubation overnight at $4{ }^{\circ} \mathrm{C}$, wells were washed with $154 \mathrm{mmol} / \mathrm{l} \mathrm{NaCl}$ containing $0.5 \mathrm{ml} / 1$ Tween 20 , then blocked with $5 \mathrm{~g} / \mathrm{l}$ bovine serum albumin in phosphate-buffered saline, $\mathrm{pH} 7.4$. Thereafter $0.05 \mathrm{ml}$ of the $1: 4$ diluted samples and $0.05 \mathrm{ml}$ of $1: 1000$ diluted rabbit antiserum were added to the wells. Plates were incubated for $1 \mathrm{~h}$ at room temperature and overnight at $4{ }^{\circ} \mathrm{C}$. Then wells were washed again and developed with a peroxidase-conjugated antirabbit IgG from sheep, using $o$-phenylenediamine as substrate. Immunoreactivity of samples was expressed as equivalents per litre (eq/l), one eq/1 corresponding to the amount of antibody-reactive material found in advanced glycation end products human albumin at a protein concentration of $1 \mathrm{mg} / \mathrm{l}$. The intra-assay coefficient of variation was $7.1 \%$ (mean value $=118 \mathrm{eq} / \mathrm{l}, \mathrm{n}=16$ ), while the inter-assay coefficient of variation was $8.2 \%$ (mean value $=26$ eq/l, $n=37$ ). The same values for advanced glycation end products were obtained for serum and for lithium heparinate plasma (16).

Serum fructosamine was assayed with a test kit from Boehringer, Mannheim, Germany, according to the supplier's instructions, and results were expressed on the basis of the serum protein content. Creatinine was determined by the Jaffe, and serum protein by the biuret reaction on a Hitachi 717 multichannel analyser (Boehringer, Mannheim, Germany).

Statistical evaluation was performed according to the instructions of Sachs (23). Statistical significance was calculated by the U-test of Mann-Whitney and Wilcoxon. Significance was taken as $\mathrm{p}<0.05$. Results are given as mean values \pm SD.

\section{Results}

Results of advanced glycation end products measurement in serum are given in table 1 . In apparently healthy persons serum advanced glycation end products concentrations ranged from 25 to 50 eq/l. From these data a refer- ence range of 21-49 eq/1 was calculated (mean value $\pm 2 \mathrm{SD}$ ). No relationship existed between serum advanced glycation end products values and age in normal controls. As serum levels of advanced glycation end products are thought to be dependent on renal elimination, diabetic patients are presented in groups according to the severity of their renal impairment. Apparently, serum advanced glycation end products values increase with decreasing kidney function, the highest values being displayed by diabetics with end-stage renal disease on haemodialysis or continuous ambulatory peritoneal dialysis. No significant difference in advanced glycation end products content was observed between diabetic and nondiabetic patients requiring haemodialysis or continuous ambulatory peritoneal dialysis. Surprisingly, advanced glycation end products values in sera from non-diabetics with end-stage renal failure not treated by dialysis are not different from normal controls. Diabetic and non-diabetic subjects treated with continuous ambulatory peritoneal dialysis showed considerably higher advanced glycation end products concentrations than subjects treated by haemodialysis $(84 \pm 23.2 \mathrm{eq} / \mathrm{l}, \mathrm{n}=8$ and $64 \pm 25.4 \mathrm{eq} / \mathrm{l}$, $\mathrm{n}=37, \mathrm{p}<0.05)$, respectively. No correlation existed in diabetic and uraemic patients between serum advanced glycation end products and creatinine.

In order to get more insight into the mechanism leading to the elevation of serum advanced glycation end products in non-diabetic uraemics on haemodialysis or continuous ambulatory peritoneal dialysis, the serum fructosamine content was determined. Assuming that glucose-containing dialysis fluids may favour advanced glycation end products formation, one might expect that serum protein glycation would be increased too. In the group of non-diabetic uraemics without dialysis one out of seven patients (14.3\%) displayed a slightly elevated fructosamine level, while in non-diabetic uraemics undergoing dialysis 9 out of 19 subjects (47.4\%) had increased fructosamine values. The difference between the two groups, however, is not statistically significant $(271 \pm 28.4 \mu \mathrm{mol} / \mathrm{l}, \mathrm{n}=7$ and $289 \pm 47.1 \mu \mathrm{mol} / \mathrm{l}$, $\mathrm{n}=19$ ). In uraemic patients without dialysis no correlation existed between advanced glycation end products and fructosamine levels $(r=-0.064)$, whereas a weak but statistically significant relationship was observed between advanced glycation end products and fructosamine in non-diabetic subjects on dialysis $(r=0.436$, $\mathrm{p}<0.05$ ) (fig. 1).

In non-diabetic, non-uraemic patients with various other diseases no statistically significant difference in serum advanced glycation end products content was observed as compared to normal controls. Details of these latter patients are presented in table 2 . As may be seen, three out of 12 patients displayed elevated serum advanced glycation end products values. This increase occurred in severly ill patients whose blood; samples were drawn 
Tab. 1 Advanced glycation end products concentrations in sera from normal controls, diabetics, patients with end-stage renal failure and with other diseases.

\begin{tabular}{|c|c|c|c|c|c|c|c|c|}
\hline & \multirow[t]{2}{*}{$\mathrm{n}$} & \multicolumn{4}{|c|}{ Serum advanced glycation end products (eq/l) } & \multicolumn{3}{|c|}{ Serum creatinine $(\mu \mathrm{mol} / \mathrm{l})$} \\
\hline & & Mean value & SD & Range & $\mathrm{p}^{\mathbf{a}}$ & Mean value & SD & Range \\
\hline Normal controls & 25 & 35 & 7.1 & $25-50$ & & 80 & 8.8 & $71-97$ \\
\hline Diabetics without renal failure & 32 & 40 & 14 & $17-74$ & n.s. & 83 & 16.8 & $62-124$ \\
\hline Diabetics with moderate renal failure & 24 & 47 & 24.7 & $20-129$ & n.s. & 186 & 84 & $80-425$ \\
\hline Uraemic diabetics & 8 & 53 & 23.5 & $22-87$ & n.s. & 522 & 133 & $292-690$ \\
\hline $\begin{array}{l}\text { Uraemic diabetics on } \\
\text { haemodialysis or continuous } \\
\text { ambulatory peritoneal dialysis }\end{array}$ & 21 & 66 & 25.2 & $28-120$ & $<0.0005$ & 611 & 154 & $310-903$ \\
\hline Uraemic non-diabetics & 7 & 33 & 14.6 & $21-64$ & n.s. & 540 & 204 & $301-876$ \\
\hline $\begin{array}{l}\text { Uraemic non-diabetics on } \\
\text { haemodialysis or continuous } \\
\text { ambulatory peritoneal dialysis }\end{array}$ & 24 & 69 & 27.1 & $34-113$ & $<0.0005$ & 788 & 191 & $416-1336$ \\
\hline Patients with various diseases & 12 & 41 & 20.2 & $17-87$ & n.s. & 115 & 58 & $53-283$ \\
\hline
\end{tabular}

a Compared with controls

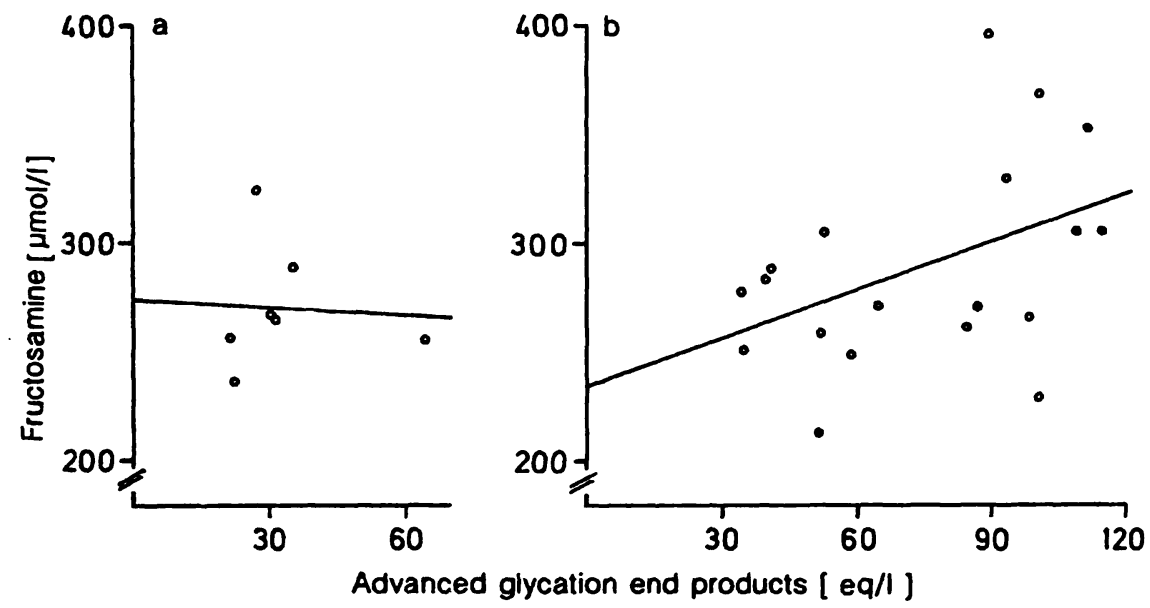

Fig. 1 Correlation between serum advanced glycation end products and fructosamine concentrations in non-diabetic uraemics without dialysis (a) and in non-diabetic uraemics treated with haemodialysis (o) or continuous ambulatory peritoneal dialysis (o) (b).

Tab. 2 Advanced glycation end products concentrations in patients suffering from diseases not related to diabetes mellitus or renal failure.

\begin{tabular}{|c|c|c|c|c|c|}
\hline Case & Clinical diagnosis & $\begin{array}{l}\text { Age } \\
\text { (years) }\end{array}$ & $\begin{array}{l}\text { Serum creatinine } \\
(\mu \mathrm{mol} / 1)\end{array}$ & Urinary protein & $\begin{array}{l}\text { Advanced glycation } \\
\text { end products (eq/l) }\end{array}$ \\
\hline 1 & Cerebral cramps & 64 & 80 & $(+)$ & 23 \\
\hline 2 & Coronary heart disease, cardiac insufficiency & 66 & 97 & negative & 47 \\
\hline 3 & Coronary heart disease, stroke & 68 & 88 & negative & 17 \\
\hline 4 & $\begin{array}{l}\text { Cirrhosis of the liver disseminated } \\
\text { intravascular coagulation, exitus }\end{array}$ & 55 & 142 & negative & 39 \\
\hline 5 & Infarction of cerebellum & 76 & 97 & negative & 31 \\
\hline 6 & Cirrhosis of the liver & 48 & 124 & n.d.* & 27 \\
\hline 7 & E. coli sepsis, exitus & 70 & 283 & n.d.* & 87 \\
\hline 8 & Acute pulmonary embolism, exitus & 79 & 97 & n. d.* & 51 \\
\hline 9 & Intoxication by ethanol & 18 & 53 & n. d.* & 29 \\
\hline 10 & M. Waldenström, exitus & 67 & 106 & negative & 33 \\
\hline 11 & Coronary heart disease, cardiac insufficiency & 88 & 88 & negative & 39 \\
\hline 12 & Ventricular fibrillation, exitus & 81 & 124 & negative & 70 \\
\hline
\end{tabular}


Tab. 3 Serum advanced glycation end products concentrations as related to diabetic late complications.

\begin{tabular}{|c|c|c|c|c|c|}
\hline & \multirow[t]{2}{*}{$\mathrm{n}$} & \multicolumn{4}{|c|}{ Serum advanced glycation end products (eq/l) } \\
\hline & & Mean value & $\mathrm{SD}$ & Range & $\mathrm{p}^{*}$ \\
\hline Normal controls & 25 & 35 & 7.1 & $25-50$ & \\
\hline Diabetics without late complications & 18 & 35 & 7.2 & $25-52$ & n.s. \\
\hline Diabetics with retinopathy & 20 & 53 & 24.3 & $22-i 129$ & $<0.0025$ \\
\hline Diabetics with nephropathy & 32 & 48 & 24.1 & $20-129$ & $<0.05$ \\
\hline Diabetics with peripheral macroangiopathy & 12 & 56 & 28.1 & $24-129$ & $<0.0025$ \\
\hline Diabetics with cerebral macroangiopathy & 7 & 53 & 24.8 & $20-87$ & n.s. \\
\hline Diabetics with coronary heart disease & 19 & 46 & 21.6 & $17-87$ & n.s. \\
\hline Diabetics with neuropathy & 12 & 53 & 26.2 & $24-129$ & $<0.0025$ \\
\hline
\end{tabular}

* Compared with controls

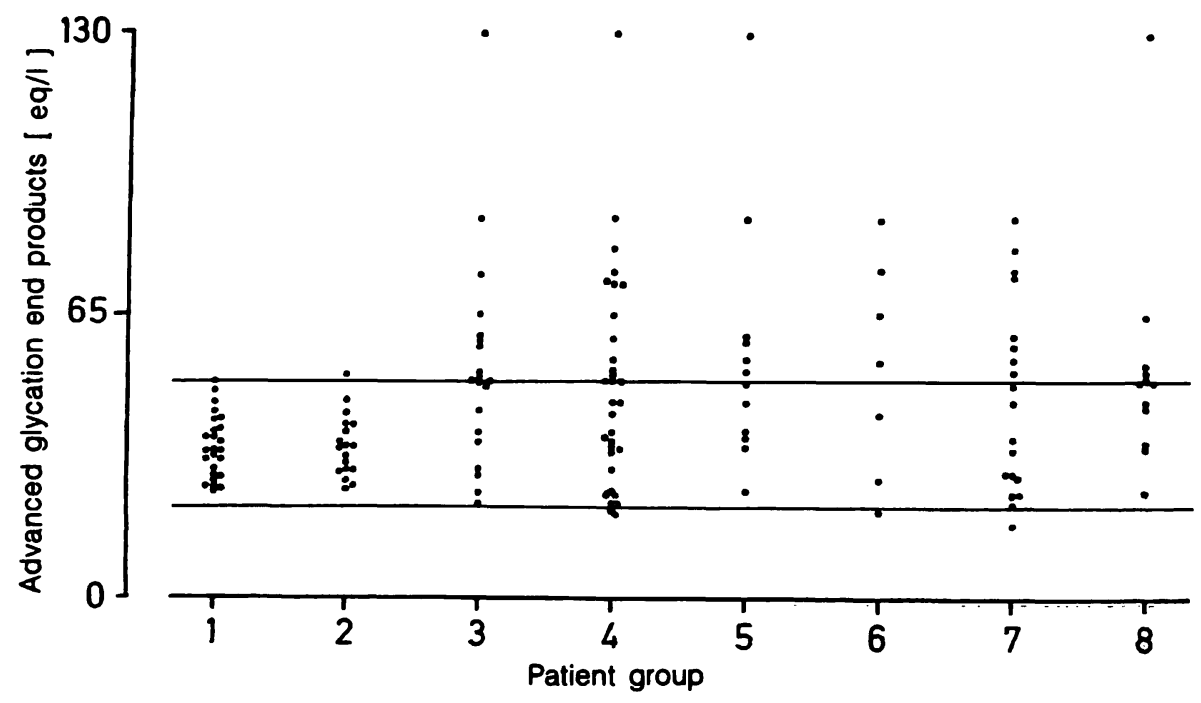

Fig. 2 Levels of serum advanced glycation end products related to diabetic sequelae.

Patient groups:

1, Normal controls;

2, diabetics without late complications;

3 , diabetics with retinopathy;

4 , diabetics with nephropathy (moderate renal failure and uraemics without haemodialysis or continuous ambulatory peritoneal dialysis);

shortly before death. In patients with diseases not related to diabetes or renal failure, a significant $(p<0.01)$ relationship between advanced glycation end products and creatinine was discernible $(r=0.767)$.

In order to determine whether serum advanced glycation end products levels might be associated with the occurrence of diabetic late complications, correlations were sought between advanced glycation end products values and the presence of diabetic sequelae. Results are given in table 3 and figure 2 . As may be clearly seen, advanced glycation end products values in diabetics without late complications are not different from results found in normal controls. In contrast, advanced glycation end products mean values are increased in the presence of sequelae. A highly significant difference versus controls was found in patients with retinopathy, peripheral macroangiopathy and with polyneuropathy, while the
5 , diabetics with peripheral macroangiopathy;

6 , diabetics with cerebral macroangiopathy;

7 , diabetics with coronary heart disease;

8 , diabetics with neuropathy.

The horizontal lines indicate the lower and upper limit of the reference range $(21-49$ eq/1).

advanced glycation end products concentration in patients suffering from cerebral macroangiopathy and coronary heart disease was not different from normal controls. It should be mentioned, however, that in the presence of sequelae, advanced glycation end products levels could be normal or even slightly decreased, the latter occurring mainly in patients with nephropathy. In the case of retinopathy and nephropathy, the advanced glycation end products content was related to the severity of retinal and renal status; results are given in table 4. The mean value of advanced glycation end products in background retinopathy amounted to $37 \pm 11.6 \mathrm{eq} / \mathrm{l}$, and did not differ from the values observed in diabetics without late complications, whereas in proliferative retinopathy, values of $61 \pm 28.9 \mathrm{eq} / 1$ were observed. In contrast, in nephropathy advanced glycation end products levels and albuminuria are not interreläted. Advanced glycation end products concentrations in normo-albu- 
Tab. 4 Relationship between serum advanced glycation end products concentrations and severity of diabetic retinopathy and nephropathy.

\begin{tabular}{|c|c|c|c|c|c|}
\hline & \multirow[t]{2}{*}{$\mathbf{n}$} & \multicolumn{4}{|c|}{ Serum advanced glycation end products (eq/l) } \\
\hline & & Mean value & SD & Range & $\mathrm{p}^{*}$ \\
\hline Diabetics without late complications & 18 & 35 & 7.2 & $25-52$ & \\
\hline $\begin{array}{l}\text { Diabetics with } \\
\text { background retinopathy } \\
\text { proliferative retinopathy }\end{array}$ & $\begin{array}{l}7 \\
9\end{array}$ & $\begin{array}{l}37 \\
61\end{array}$ & $\begin{array}{l}11.6 \\
28.9\end{array}$ & $\begin{array}{l}22-50 \\
29-129\end{array}$ & $\begin{array}{l}\text { n.s. } \\
<0.005\end{array}$ \\
\hline $\begin{array}{l}\text { Diabetics with } \\
\text { normoalbuminuria } \\
\text { microalbuminuria } \\
\text { gross proteinuria }\end{array}$ & $\begin{array}{r}8 \\
7 \\
21\end{array}$ & $\begin{array}{l}42 \\
36 \\
44\end{array}$ & $\begin{array}{l}15.1 \\
11.8 \\
25\end{array}$ & $\begin{array}{l}25-72 \\
21-58 \\
20-129\end{array}$ & $\begin{array}{l}\text { n.s. } \\
\text { n.s. } \\
\text { n.s. }\end{array}$ \\
\hline
\end{tabular}

* Compared with diabetics without late complications

minuria (albumin $<30 \mathrm{mg} / \mathrm{g}$ creatinine), microalbuminuria $(30-300 \mathrm{mg} / \mathrm{g}$ creatinine), and in gross proteinuria (>300 mg/g creatinine) were $42 \pm 15.1 \mathrm{eq} / \mathrm{l}, 36 \pm 11.8$ eq/l and $44 \pm 25 \mathrm{eq} / \mathrm{l}$, respectively. It is noteworthy that advanced glycation end products levels are not related to the total number of late complications exhibited by any one patient.

\section{Discussion}

Occurrence of advanced glycation end products in serum and their increase in diabetics and patients with endstage renal disease is now well established $(13-16,24-$ 28). From these studies, it is reasonable to assume that elevation of serum advanced glycation end products may be caused by increased formation during hyperglycaemia and uraemia or by decreased elimination due to renal failure or ineffective dialysis procedures. However, our results raise certain questions as to the cause of the elevation of serum advanced glycation end products in patients with kidney disease. Although the values for advanced glycation end products in diabetics tended to increase with impairment of kidney function, no correlation existed between advanced glycation end products levels and serum creatinine or albuminuria. Further, in contrast to Papanastasiou et al. (26), we found no increase in advanced glycation end products values in non-diabetic patients with end-stage renal disease, not yet dialysed, but hospitalised for receiving their first dialysis session, whereas dialysed subjects displayed high values. From this result, one might speculate that formation of advanced glycation end products is triggered by factors in the dialysis procedures, i. e. glucose-containing fluids. This view is further substantiated by the facts that

1) glycation of serum proteins, as revealed by fructosamine measurement, is increased in about $50 \%$ of nondiabetic uraemics on dialysis and is related to advanced glycation end products levels;
2) patients undergoing continuous ambulatory peritoneal dialysis displayed essentially higher advanced glycation end products levels than subjects on haemodialysis;

3) elevation of advanced glycation end products in subjects with end-stage renal disease on haemodialysis or continuous ambulatory peritoneal dialysis is essentially the same in the absence and in the presence of diabetes;

4) advanced glycation end products levels determined before and after a dialysis session were found to be increased after dialysis in about $50 \%$ of cases, as reported previously (16);

5) advanced glycation end products levels declined after kidney transplantation (13).

Further extensive work is necessary to examine the possible origin of serum advanced glycation end products in subjects with end-stage renal disease.

In diabetics, we showed for the first time that serum advanced glycation end products levels are related to diabetic late complications, patients without sequelae displaying values within the normal range, while in the presence of complications mean advanced glycation end products values are increased. An association between serum advanced glycation end products and severity of retinopathy but not of nephropathy was discernible. Varying results were obtained when pentosidine $(29,30)$ or fluorescence (31) were determined in human skin collagen, showing correlations with retinopathy (31), nephropathy (30) or both (29). Our present findings and previous studies strongly indicate a link between advanced glycation end products and diabetic late complications in certain cases. However, it is still unknown whether high serum advanced glycation end products levels contribute to the pathogenesis of late complications or whether serum levels are increased due to degradation products derived from highly glycated tissues. Data from Vlassara et al. (32), however, indicate, that serum advanced glycation end products might be patho- 
genic, as rat advanced glycation end products albumin administered to normal rats induced glomerular sclerosis and albuminuria. As demonstrated here, about half of the patients with late complications showed normal or even decreased serum advanced glycation end products levels. Unfortunately, in peripheral macroangiopathy and polyneuropathy, a staging according to the severity of complication was not possible. Further, it should be mentioned that advanced glycation end products, if they are really pathogenic, might be one component of a variety of factors leading to the development of diabetic late complications.

The apparent increase in serum advanced glycation end products in diabetics in relation to decreasing renal function (tab. 1) may be due to the presence of late complications. In the group of diabetics without renal failure, 15 patients suffered from late complications, while 19 out of the 24 diabetics with moderate renal failure displayed sequelae other than nephropathy, and six out of the eight uraemic diabetics suffered from proliferative retinopathy. Finally, one might assume that elevated advanced glycation end products levels in patients on haemodialysis or continuous ambulatory peritoneal dialysis are involved in the development of complications of dialysis, resembling diabetic late complications.

\section{References}

1. Wieland $\mathrm{OH}$. Protein modification by nonenzymatic glucosylation: possible role in the development of diabetic complications. Mol Cell Endocrinol 1983; 29:125-31.

2. Ledl F, Schleicher E. Die Maillard-Reaktion in Lebensmitteln und im menschlichen Körper - neue Ergebnisse zur Chemie, Biochemie und Medizin. Angew Chemie 1990; 102:597-626.

3. Eble AS, Thorpe SR, Baynes JW. Nonenzymatic glycosylation and glucose-dependent cross-linking of proteins. J Biol Chem 1983; 258:9406-12.

4. Brownlee $M$, Vlassara $H$, Cerami A. Nonenzymatic glycosylation products on collagen covalently trap low-density lipoprotein. Diabetes 1985; 34:938-41.

5. Kristal BS, Byung PY. An emerging hypothesis: synergistic induction of aging by free radicals and Maillard reactions. $J$ Gerontol 1992; 47:B107-14.

6. Bucala R, Tracey K, Cerami A. Advanced glycosylation products quench nitric oxide and mediate defective endotheliumdependent vasodilation in experimental diabetes. $\mathrm{J}$ Clin Invest 1991; 87:432-8.

7. Vlassara $H$, Brownlee $M$, Manogue $K R$, Dinarello $C$, Pasagian A. Cachectin/TNF and IL-1 induced by glucose modified proteins: role in normal tissue remodeling. Science 1988; 240:1546-8.

8. Doi T, Vlassara H, Kirstein M, Yamada Y, Striker GE, Striker LJ. Receptor-specific increase in extracellular matrix production in mouse mesangial cells by advanced glycosylation endproducts is mediated via platelet-derived growth factor. Proc Natl Acad Sci USA 1992; 89:2873-7.

9. Vlassara $H$, Bucala $R$, Striker L. Pathogenic effects of advanced glycosylation: biochemical, biologic, and clinical implications for diabetes and aging. Lab Invest 1994; 70:138-51.

10. Hayase F, Nagaraj RH, Miyata S, Njoroge FG, Monnier VM. Aging of proteins: immunological detection of a glucose-derived pyrrole formed during Maillard reaction in vivo. J Biol Chem 1989; 263:3758-64.
The observations in non-diabetic, non-uraemic patients indicate that an increase in serum advanced glycation end products is not confined to diabetics and patient with renal disease, but also occurs in certain severely ill subjects shortly before their death. Similar results were obtained by Sell \& Monnier (28) when measuring pentosidine in skin collagen. The reason(s) for this phenomenon is still unknown.

The nature of the immunologically reactive material is not yet known. Epitopes may be bound to intact proteins, peptides, amino acids or other still unknown compounds. Further work is necessary to characterise and to identify the immunologically reactive structures and to examine their possible pathophysiological role in the development of diabetic late complications.

\section{Acknowledgements}

We thank Professor Dr. J. Mann (6. internal medicine department) and the medical staff of the 2., 3., and 6. internal medicine department of Städtisches Krankenhaus München-Schwabing for permission and help to study patients under their care. We are grateful to Mr. Kampe, Institut für Medizinische Informationsverarbeitung, Biometrie und Epidemiologie, Ludwig-Maximilians-Universität München, for help in statistical evaluation. This work was supported by the Deutsche Forschungsgemeinschaft, Bonn-Bad Godesberg, Germany.
11. Sell DR, Monnier VM. Structure elucidation of a senescence cross-link from human extracellular matrix. J Biol Chem 1989; 264:21597-602.

12. Knecht KJ, Feather MS, Baynes JW. Detection of 3-deoxyfructose and 3-deoxyglucosone in human urine and plasma: evidence for intermediate stages of the Maillard reaction in vivo. Arch Biochem Biophys 1992; 294:130-7.

13. Makita Z, Radoff S, Rayfield EJ, Yang Z, Skolnik E, Delaney $\mathrm{V}$, et al. Advanced glycosylation end products in patients with diabetic nephropathy. N Engl J Med 1991; 325:836-42.

14. Odetti P, Fogarty J, Sell DR, Monnier VM. Chromatographic quantitation of plasma and erythrocyte pentosidine in diabetic and uremic subjects. Diabetes 1992; 41:153-9.

15. Makita Z, Bucala R, Rayfield EJ, Friedman EA, Kaufmann $\mathrm{AM}$, Korbet SM, et al. Reactive glycosylation end products in diabetic uraemia and treatment of renal failure. Lancet 1994; 343:1519-22.

16. Dolhofer-Bliesener R, Lechner B, Deppisch R, Ritz E, Gerbitz $\mathrm{KD}$. Immunological determination of advanced glycosylation end-products in human blood and urine. Nephrol Dial Transplant 1995; 10:657-64.

17. Monnier VM, Cerami A. Nonenzymatic browning in vivo: possible process for aging of long-lived proteins. Science $1981 ; 211: 491-3$.

18. Chio KS, Tappel AL. Synthesis and characterization of the fluorescent products derived from malondialdehyde and amino acids. Biochemistry 1969; 8:2827-32.

19. Wickens DG, Norden AG, Lunec J, Dormandy TL. Fluorescence changes in human gamma-globulin induced by free-radical activity. Biochim Biophys Acta 1983; 742:607-16.

20. Le Guen CA, Jones AF, Barnett AH, Lunec J. Role of reactive oxygen species in the generation of fluorescence by glycation. Ann Clin Biochem 1992; 29:184-9.

21. Nakayama H, Taneda S, Kuwajima S, Aoki S, Kuroda Y, Misawa $\mathrm{K}$, et al. Production and charactérization of antibodies to 
advanced glycation products on proteins. Biochem Biophys Res Commun 1989; 162:740-5.

22. Dolhofer-Bliesener $\mathrm{R}$, Lechner $\mathrm{B}$, Gerbitz $\mathrm{KD}$. Impaired immunoglobulin G Fc fragment function in diabetics is caused by a mechanism different from glycation. Eur $\mathrm{J}$ Clin Chem Clin Biochem 1994; 32:329-36.

23. Sachs L. Angewandte Statistik, Berlin: Springer Verlag, 1974.

24. Makita Z, Vlassara $H$, Cerami A, Bucala R. Immunochemical detection of advanced glycosylation end products in vivo. $J$ Biol Chem 1992; 267:5133-8.

25. Korbet S, Makita Z, Firanek CA, Vlassara H. Advanced glycosylation end products in continuous ambulatory peritoneal dialysis patients. Am J Kidney Dis 1993; 22:588-91.

26. Papanastasiou P, Grass L, Rodela H, Patrikarea A, Oreopoulos D, Diamandis EP. Immunological quantification of advanced glycosylation end-products in the serum of patients on hemodialysis or CAPD. Kidney Int 1994; 46:216-22.

27. Taneda S, Monnier VM. ELISA of pentosidine, an advanced glycation end product, in biological specimens. Clin Chem 1994; 40:1766-73.

28. Sell DR, Monnier VM. End-stage renal disease and diabetes catalyze the formation of a pentose-derived crosslink from aging human collagen. J Clin Invest 1990; 85:380-4.
29. McCance DR, Dyer DG, Dunn JA, Bailie KE, Thorpe SR, Baynes JW, et al. Maillard reaction products and their relation to complications in insulin-dependent diabetes mellitus. J Clin Invest 1993; 91:2470-8.

30. Beisswenger PJ, Moore LL, Brinck-Johnson T, Curphey TJ. Increased collagen-linked pentosidine levels and advanced glycosylation end products in early diabetic nephropathy. $\mathrm{J}$ Clin Invest 1993; 92:212-7.

31. Monnier VM, Vishwanath V, Frank KE, Elmets CA, Dauchot P, Kohn RR. Relation between complications of type I diabetes mellitus and collagen-linked fluorescence. $N$ Engl J Med 1986; 314:403-8.

32. Vlassara H, Striker LJ, Teichberg S, Fuh H, Li YM, Steffes $M$. Advanced glycation end products induce glomerular sclerosis and albuminuria in normal rats. Proc Natl Acad Sci USA 1994; 91:11704-8.

Received September 25, 1995/January 3, 1996

Corresponding author: Dr. Roswitha Dolhofer-Bliesener, Städtisches Krankenhaus München-Schwabing, Institut für Klinische Chemie, Kölner Platz 1, D-80804 München, Germany 
